\title{
Larvicidal Activity of A Mixture of Cashew Nut Shell Liquid and Water-Soluble Extract of Soap Nut Fruit (Sapindus rarak DC.) Against $3^{\text {rd }}$ Instar Larvae of Aedes aegypti
}

\author{
Glory Resia Raraswati ${ }^{1}$, Sudarsono ${ }^{2}$ and Budi Mulyaningsih ${ }^{3}$ \\ ${ }^{1}$ Faculty of Pharmacy; ${ }^{2}$ Laboratory of Parasitology Faculty of Medicine; ${ }^{3}$ Department of Pharmaceutical Biology, UGM, Indonesia
}

Author correspondency:

Sudarsono: ugmpsot@yahoo.com; Budi Mulyaningsih: budimulyaningsih@yahoo.com

\begin{abstract}
Cashew Nut Shell Liquid (CNSL) which has been known as a waste of processing cashew fruits which is contain phenolic compounds have activity as larvicides. Cashew nut shell liquid is not soluble in the water where the larvae grow. Cashew nut shell liquid mixed with watersoluble extract of soapnut fruit which serves as a natural surfactant that can emulsify oil in water. The test subjects were larvae of Aedes aegypti third instar. Test subjects were divided into treatment group and control group. In the treatment group, test subjects were the mixture of CNSL and Ethylacetat Soluble Extract (ESE) in tap water. The Larvae mortality observations were done 24 hours after the treatment. $\mathrm{LC}_{50}$ and $\mathrm{LC}_{90}$ as final test data were analyzed using probit analysis. Extract constituents of CNSL and Water Soluble Extract of SoapNut fruit (WSEoSN) were investigated using Thin Layer Chromatography (TLC) method. The effect of CNSL as larvicides against third instar larvae of Ae. aegypti with were $\mathrm{LC}_{50}$ of $14,12 \mathrm{ppm}$, while the $\mathrm{LC}_{90}$ of $24,85 \mathrm{ppm}$.
\end{abstract}

Keywords: Larvacidal activity, Thin Layer Chromatography, Sapindus rarak DC

\section{Introduction}

Aedes aegypti is a mosquito species that can carry and transmit the dengue virus causes Dengue Hemor rhagic Fever (DHF), yellow fever virus and chikungunya virus (WHO, 2004). How to control the mosquito population that most rapidly break the cycle of transmission is the use of chemical compounds, one of them is the use of synthetic insecticides and larvicides. The use of synthetic compounds can lead to increased mos quito resistance, environmental pollution caused by their residue, even the death of non-target creatures (Munif, 1993). The use of plants as a biopesticide is a one of alternative natural way for controlling which is safer for sustainable environment balance. The natural biopesticides were usually easy to apply and not harmful to natural enemies and other beneficial insects (Adebowale \& Adedire, 2006).

CNSL is a viscous oil, black color and has a very strong irritant properties on the skin because of the phenolic substances derivatives e.g. Cardol, anacardic acid and 2-methyl kardol (Kubo et al., 1986); anacardic acid is not soluble in water. This sticky fluid was extracted from cashew nut shell by the use of hydraulic pressure pump at a certain temperature (Mulyono and Abdul Gani, 1996). Anacardic acid has several biologic effect such as anti-microbial, anti-acne (Kubo et al., 1993; 1994) and as molluscicides (Kubo et al., 1986). The main constituent of CNSL i.g. anacardic acid, cardanol, and cardol also reported as larvicidal activity against the larvae of $A$ e. aegypti with $\mathrm{LC}_{50}$ of $12,40 \mathrm{ppm}$ for anacardic acid, 14,45 ppm for cardanol, and 10,22 ppm for cardol (Oliveira et al., 2010).

Soapnut in Indonesia called "Lerak" (Sapindus rarak DC.) is a plant that from Southeast Asia and can be able grow well in tropical climate such in Indonesia (Afriastini, 1990). The active compounds from the soapnut pericarp are saponins - and sesquiterpenecompounds. The main of non-sugar saponins compound are usually triterpenes and steroids derivatives (Schneider, 1980; Wina et al., 2005).Saponins as well as surfactants that have both hydrophilic and hydrophobic pool which were able to lower the interfacial tension between oil and water that immiscible; so as to form a colloidal solution which forms a foam when shaken (Matheson, 1996; Gunawan \& Mulyani, 2004).

The purpose of this study was to determine the activity of cashew nut shell oil (Cashew Nut Shell Liquid / CNSL) as an alternative natural larvicides.

\section{Methodology}

\section{Preparation and extraction of plant materials}

Cashew nut shell obtained from Jatibedug village, Wonogiri and soapnut fruit from Perhutani area, Situbondo. The identification of plant material was carried out by Mr.Joko santosa M.Si, and voucher specimen was found at the Department of pharmaceutical biology Faculty of Pharmacy, UGM, Yogyakarta. Cashew nut shell that had been oven-dried at $50^{\circ} \mathrm{C}$ for 1 hour obtained $1,313 \mathrm{~kg}$ net weight then pressed using a hydraulic press by $150-160 \mathrm{~kg} / \mathrm{cm}^{2}$ to obtain Cashew Nut Shell Liquid (CNSL); whereas $10 \mathrm{~g}$ of soapnut fruit chopped and then extracted by heating at $50^{\circ} \mathrm{C}$ for $30 \mathrm{~min}$ in the distilled water ad $1000 \mathrm{ml}$ to obtain a water-soluble extract of soapnut fruit $1 \% \mathrm{~b} / \mathrm{v}$. 


\section{Preparation of water-soluble extract of soapnut fruit which did not kill larvae}

As a main solution of water-soluble extract of soapnut fruit was $1 \% \mathrm{~b} / \mathrm{v}$ diluted by taking a volume of $6,8,10$, and $12 \mathrm{~mL}$ for each dissolved in $100 \mathrm{~mL}$ of tap water to obtain test solutions with concentrations of 600,800 , 1000, and $1200 \mathrm{ppm}$. Four plastic cups with a mouth diameter of approximately $10 \mathrm{~cm}$ glass used as a test medium. Each test cups contain 10 larvae of third instar Ae. aegypti. Each concen-tration of repetitions performed 3 times. Larval mortality was observed 24 hours after treatment by calculating the percentage of larval mortality. The biggest concentrations that doesn't kill any larvae chosen for making the mixture solution with cashew nut shell liquid.

\section{Bioassay for larvicidal toxicity}

Mixture concentration series was made by mixing watersoluble extract of soapnut fruit at a concentration elected with cashew nut shell liquid. The mixture of CNSL and water soluble extract of soapnut fruit homogenized using a vortex for 5 minutes, then stirred using a magnetic stirrer at medium speed for 5 minutes. The results observed visually mixing at room temperature $\left(25^{\circ} \mathrm{C}\right)$. Subsequently the mixture was dissolved in tap water to obtain a final volume of $100 \mathrm{~mL}$ of solution for each concentration. The CNSL concentration used was $6 \mathrm{ppm}$, 7,56 ppm, 9,53 ppm, 12,01 ppm, 15,13 ppm, and 19,06 ppm. Each test cups contain 25 larvae of third instar $A e$. aegypti. Each concentration of repetitions performed 3 times. Larval mortality was observed 24 hours after treatment by calculating the percentage of larval mortality. Larvicidal test data were analyzed using probit analysis to obtain $\mathrm{LC}_{50}$ and $\mathrm{LC}_{90}$ (Finney, 1971). The concentrations in probit analysis were transformed to logarithm (Log concentra-tion) and the lethal concentrations $\left(\mathrm{LC}_{50}\right.$ and $\left.\mathrm{LC}_{90}\right)$ were calculated manually.

\section{Specification of test material using Thin Layer Chromatography (TLC)}

a. Cashew nut shell liquid

Cashew nut shell liquid that dissolved in n-hexane $\left(1: 10^{\mathrm{b}} / \mathrm{v}\right)$ and then filtered with silica gel 60 used as test solution. Components of CNSL are further separated by Thin Layer Chromatogra phic (TLC) method. Chromtography was perfomed using aluminium plates silica gel $60 \mathrm{~F}_{254}$ (Merck). Three microliters of test solution was applied to the plate with distance of development $8 \mathrm{~cm}$. Plate inserted in a chamber that had already saturated by mobile phase $\mathrm{n}-$ toluene: ethyl acetate: glacial acetic acid $(7: 2: 1 \mathrm{v} / \mathrm{v} / \mathrm{v})$. After development the mobile phase was evaporated to dryness and plates were sprayed with iodine vapor and vanillin sulfuric acid. b. Water-soluble extract of the soapnut fruit

Thirty milliliters of water-soluble extract of soapnut fruit was evaporated and then hydrolyzed by boiling with $30 \mathrm{~mL}$ of $2 \mathrm{~N} \mathrm{HCl}$ using reflux distillation method for 30 minutes. Samples that had been hydrolyzed were then fractionated with $30 \mathrm{~mL}$ of $\mathrm{n}$-hexane. $\mathrm{N}$ hexane fraction was then washed with distilled water until water fraction $\mathrm{pH}$ was neutral. The results of this fraction was then added anhydrous $\mathrm{Na}_{2} \mathrm{SO}_{4}$ to remove water traces. Furthermore, the fraction of n-hexane which has been neutralized partitioned again using 30 $\mathrm{mL}$ of ethyl acetate. Components of both fractions were then separated by TLC. Samples of both fractions was applied to the plate as much as 3 spots using a capillary tube with distance of development 8 $\mathrm{cm}$. Plate inserted in a chamber that has been saturated with mobile phase. Mobile phase that used was chloroform: methanol (9.5: $0.5 \mathrm{v} / \mathrm{v})$. After development the mobile phase was evaporated to dryness and plates were sprayed with anisaldehyde sulfuric acid.

\section{Results and Discussion}

\section{Larvicidal effect of a mixture of cashew nut shell liquid and water-soluble extract of soapnut fruit}

Probit analysis was used to study the response of larvae to the exposure of test solution in a biological assay (Umniyati, 1990). Probit analysis is a statistical method used to determine the relationship between dose and response (Finney, 1971). Percentage larval mortality was calculated after 24 hours. Dead larvae are larvae that does not move when touched with a pipette or larvae that sink to the bottom of container that does not respond to stimulation.

Table 1. Test results of water-soluble extract of the soapnut fruit preliminary test.

\begin{tabular}{lcccc}
\hline $\begin{array}{l}\text { Soapnut } \\
\text { concentration } \\
(\mathbf{p p m})\end{array}$ & $\mathbf{1}$ & $\mathbf{2}$ & $\mathbf{3}$ & $\begin{array}{c}\text { Total mortality of larvae } \\
\text { test }\end{array}$ \\
\hline $600\left(^{*}\right)$ & 0 & 0 & 0 & 30 \\
800 & 1 & 0 & 1 & 30 \\
1000 & 1 & 2 & 2 & 30 \\
1200 & 4 & 3 & 4 & 30 \\
\hline
\end{tabular}

In Table 1 , it can be seen that the biggest concentration of water-soluble extract of the soapnut fruit that does not make larvae dead were at a concentration $600 \mathrm{ppm}$. This preliminary test aim is to minimize the effect of watersoluble extract of the soapnut fruit in the death of larvae so the final assay results that obtained later is the result of larvicidal activity of cashew nut shell liquid. The largest concentration of water-soluble extract of soapnut fruit that does not kill larvae was used for the mixture becausehigher levels of water-soluble extract of soapnut fruit will increase the solubility of cashew nut shell liquid in the water. 
In Table 2, data percentage mortality test results are used to calculate the $\mathrm{LC}_{50}$ and $\mathrm{LC}_{90}$ values are percent mortality at levels of 7,56 ppm, 9,53 ppm, 12,01 ppm, $15,13 \mathrm{ppm}$, and $19,06 \mathrm{ppm}$. The percentage mortality data is plotted in probit tables to obtain theprobit value, then made the graph between log concentration $(\mathrm{x})$ and probit value (y) to obtain the linear regression equation $\mathrm{y}=\mathrm{a}+$ bx. Probit calculation steps performed according to the method of Finney (1971).

Table 2. Results of probit analysis of a mixture of cashew nut shell liquid and water-soluble extract of soapnut fruit against Ae. Aegyptilarvae (total larval test $=75$ ).

\begin{tabular}{llllll}
\hline $\begin{array}{l}\text { CNSL concentration } \\
(\mathbf{p p m})\end{array}$ & $\begin{array}{l}\text { Total mortality } \\
\text { of larvae }\end{array}$ & $\begin{array}{l}\text { Percentage larval } \\
\text { mortility (mean) }\end{array}$ & Linier equation & $\begin{array}{l}\text { LC50 } \\
\text { (ppm) }\end{array}$ & $\begin{array}{l}\text { LC90 } \\
(\mathbf{p p m})\end{array}$ \\
\hline 0 & 0 & 0 & & \\
6 & 0 & 0 & & \\
7,56 & 8 & 10,67 & $\mathrm{y}=5,20921 \mathrm{x}-0,9891$ & 14,12 \\
9,53 & 14 & 18,67 & & \\
12,01 & 20 & 26,57 & & \\
15,13 & 41 & 54,67 & & \\
19,06 & 60 & 80 & & \\
\hline
\end{tabular}

Linear regression equation obtained from the probit analysis is $\mathrm{y}=5.20921 \mathrm{x}-0.9891$ so that the calculation of $\mathrm{LC}_{50}$ and $\mathrm{LC}_{90}$ can be obtained.LC $\mathrm{C}_{50}$ and $\mathrm{LC}_{90}$ calculated were 14.12 ppmand $24.85 \mathrm{ppm}$.

A material that has a larvicidal test $\mathrm{LC}_{50}$ values below $100 \mathrm{ppm}$ can be said to have larvicidal activity against the larvae test (Cheng et al., 2003). $\mathrm{LC}_{50}$ values in this study were at $14.12 \mathrm{ppm}$ so cashewnutshell liquid that is used as the test material can be said to have potential as larvicidal agent against the third instar larvae of $A e$. Aegypti. Cashew nut shell oil is known to have 3 main compound content anacardic acid, cardol, and cardanol which showed inhibition of the acetylcholinesterase enzyme activity as well as the mechanism of action of organophosphate and carbamate (Oliveira et al., 2010). Inhibition of the acetylcholinesterase enzyme causes accumulation of acetylcholine which triggers central nervous system disorders, convulsions, respiratory paralysis, and death in larvae (Rosenberryet al., 2008).

\section{Phytochemical compund of cashew nut shell liquid and water-soluble extract of soapnut fruit}

In Figure 1, elution of CNSL results showed 2 spots on the $h R f 63$ and 73, that drown under $254 \mathrm{~nm}$ UV light. Furthermore, the silica plate inserted in a closed chamber that has been filled by iodine vapor and left a few minutes.

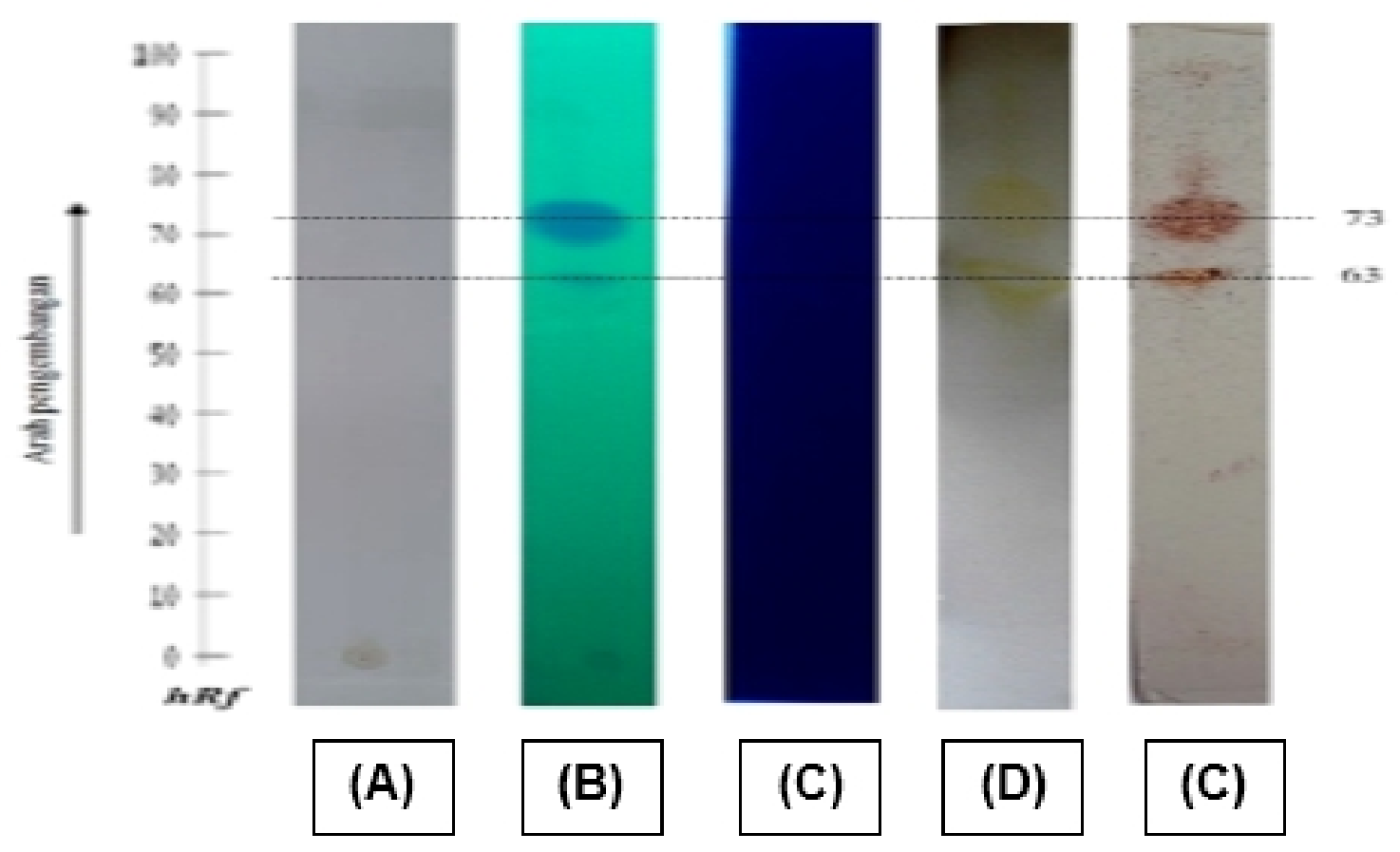

Figure 1. TLC-Chromatogram of cashew nut shell liquid. Detection: visible light (A), under $254 \mathrm{~nm}$ UV light (B), under $366 \mathrm{~nm}$ UV light (C), after iodine vaporized (D), and after spraying vanillin sulfuric acid were observed in visible light (E).

Figure 1.D were a yellow spot; the $h R f 63$ and 73. It could be the presence of an unsaturated compound; it was perhaps an side chain of the phenolic compounds. Iodine vapor was used for the detection of side chain compounds 
that had a double bond; a positive result is a yellowbrown spots on the visible light (Fessenden and Fessenden, 1994). The mechanism of iodine to form the color is an addition reaction on double bond in unsaturated fatty acids (Simpen, 2008).

Results of detection by vanillin sulfuric acid reagent (Figure 1.E) were observed under visible light were the presence of spots on $h R f 63$ with red-orange color, while on $h R f 73$ as pink-brown color spot. Based on these results, spots on the $h R f 63$ and 73 suspected as phenolic compounds anacardic acid derivatives.

Identification of the compounds in water-soluble extract of soapnut fruit was identifying saponin. Saponins are triterpenoid glycosides or glycoside steroid with sapogeninaglycone (Schneider, 1985; Gunawan and Mulyani, 2004). The basic science of saponin Identification was made for the existence of the sapogenin aglycone.

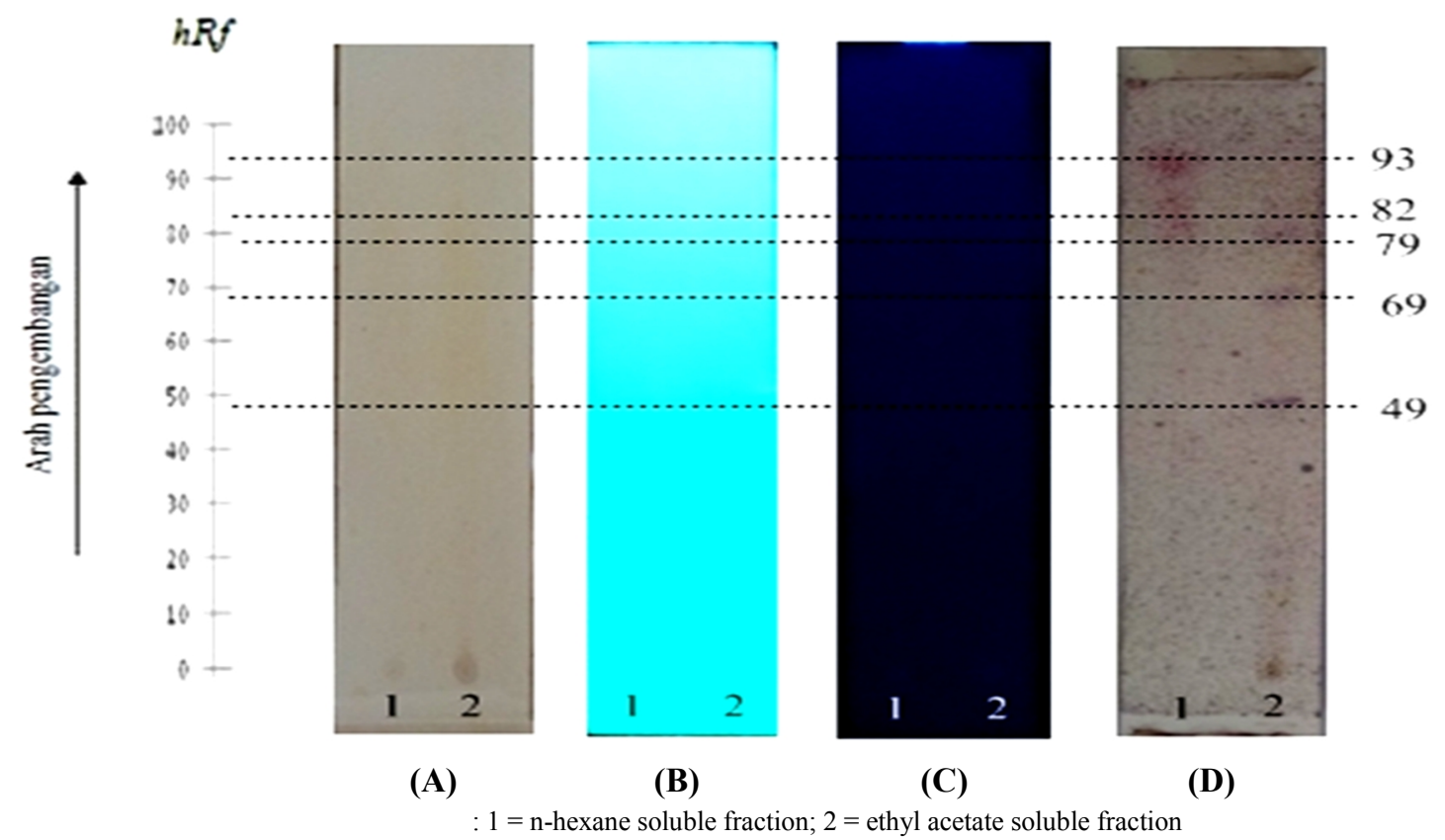

Figure 2. TLC chromatogram profile of n-hexane and ethyl acetate fraction of water-soluble extract of soapnut fruit. Detection before spraying anisaldehyde sulfuric acid: under visible light (A), UV $254 \mathrm{~nm}(\mathbf{B})$, and UV $366 \mathrm{~nm}$ (C) and detection after spraying anisaldehyde sulfuric acid under visible light (D).

In Figure 2, the chromatogram of n-hexane and ethyl acetate of water-soluble extract of soapnut fruit had no spots after observed under visible light, UV light $254 \mathrm{~nm}$, and $366 \mathrm{~nm}$ UV. It was due to saponins had no aromatic ring in the structure. It could be detected by coloring spray reagent (Wagner, 1984). If there is purple-red or purple after spraying with anisaldehyde sulfuric acid reagent showed the presence of terpenoids or steroids (Wagner \& Bladt, 1996). After spraying with anisaldehyde sulfuric acid reagent (AAS) and it was heated for 5 minutes at a temperature of $105^{\circ} \mathrm{C}$, there was 3 purple spots (hRf 49; hRf 67, and hRf 79) in ethyl acetate fraction and the fraction of $n$-hexane had pink spots on the hRf 82 and 93. The purple color in ethyl acetate fraction was a steroid sapogenin compounds, and the pink spots on $n$-hexane fraction could be as triterpene sapogenin.

Steroid compounds are more polar than the triterpenoid compounds so that would be more soluble in more polar solvents as well, in this case is ethyl acetate.

Based on the above observations, the water-soluble extract of soapnut fruit suspected of containing sapogenin steroid and triterpenoid sapogenin which is the aglycone of saponin glycosides and it can be used as a natural surfactant to emulsify cashew nut shell oil in aqueous media. The larvicidal properties exhibited by cashew nut shell liquid in this study might be related to presence of phenolic derivative components.

\section{Conclusion}

The results of this study indicated that a mixture of cashew nut shell liquid and water soluble extracts of soapnut fruit (Sapindus rarak DC.) had an effect as larvicides against third instar larvae of Ae. aegypti. Further research needs to be done about the toxicity effects of a mixture of cashew nut shell liquid and water soluble extract of soapnut fruit against non-target organisms i.g fish, and frog.

\section{References}

Adebowale, K.O. \& Adedire, C.O., 2006, Chemical composition and insectisidal properties of the underutilized Jatropha curcas seed oil. African J. Biotech. 5 (10), 901-906.

Afriastini, J.J., 1990, Daftar Jenis Nama Tanaman, 53-60, Penebar Swadaya, Jakarta.

Cheng, S.S., Chang, H.T., Chang, S.T., Tsai, K.H., Chen, W.J., 2003, Bioactivity of selected plant essential oils against the 
yellow fever mosquito Aedes aegypti larvae. Bioresource Technology, 89, 99-102.

Finney, D.J., 1971, Probit Analysis, 3rd Ed., 333-340, Cambridge University Press, Great Britain.

Gunawan, D. \& Mulyani, S., 2004, Ilmu Obat Alam (Farmakognosi), Jilid 1, 87-95, Penebar Swadaya, Depok.

Kubo, I., Muroi, H., \& Kubo, A., 1994. Naturally occurring antiacne agents, J Nat Prod, 57, 9 - 17.

Kubo, I., Muroi, H., Himejima, M., Yamagiwa, Y., Mera, H., Tokushima, K., Ohta, S., \& Kamikawa, T., 1993, Structure antibacterial activity relationships of anacardic acids, $J$ Agric Food Chem, 41, 1016-1019.

Kubo, I., Komatsu, S., \& Ochi, M., 1986, Molluscicides from cashew (Anacardium accidentale) and their largescale isolation. J. Agric. Food Chem, 34, 970-973.

Matheson, K.L., 1996, Surfactant raw materials: classification, synthesis, and uses. In Spitz, L. (ed). Soap and Detergents: A Theoretical and Practical Review, 288-303, AOCS Press, Illinois.

Mulyono, E., \& Abdulgani, L.Y., 1996, Karakterisasi CNSL dan metode ekstraksinya; Isolasi kardanol dan karakteristiknya; Isolasi pektin dan karakteristiknya, Laporan Penelitian, BALITTRO, Bogor.

Munif, A., 1993, Cendawan Patogen pada Larva Anopheles aconitus yang Resisten DPT di Daerah Endemis Malaria Banjarnegara, Jawa Tengah. Majalah Kesehatan Indonesia XXI, 8, 472-6.

Oliveira, M.S.C., de Morais, S.M., Magalhães, D.V., Batista, W.P., Vieira, I.G.P., Craveiro, A.A., de Manezes, J.E.S.A., Carvalho,
A.F.U., de Lima, G.P.G., 2010, Antioxidant, larvicidal and antiacetylcholinesterase activities of cashew nut shell liquid constituents, Acta Tropica, 117 (2011), 165-170.

Rosenberry, T.L., Sonoda, L.K., Dekat, S.E., Cusack, B., Johnson, J., 2008, Monitoring the reaction of carbachol with acetylcholinesterase by thioflavin $\mathrm{T}$ fluorescence and acetylthiocholine hydrolysis, Chem. Biol. Interact, 175, 235241.

Schneider G., 1980, Pharmazeutisch Bio logie, B.I.Varlag Mannheim p. 230

Simpen, I.N., 2008, Isolasi Cashew Nut Shell Liquid dari Kulit Biji Jambu Mete (Anacardium occidentale L) dan Kajian Beberapa Sifat Fisiko-Kimianya. Jurnal Kimia 2 (2), 71-76.

Umniyati, S.R., 1990, Analisa Probit secara Aritmatis untuk Pengujian Toksisitas Insektisida terhadap Serangga, 1-13, 2736, Laboratorium Parasitologi Fakultas Kedokteran Universitas Gadjah Mada, Yogyakarta.

Wagner, H., 1984, Plant Drug Analysis a Thin Layer Chromatography Atlas, 164, Springer, New York.

Wagner, H \& Bladt, S., 1996, Plant Drug Analysis, 2nd Ed., $305-$ 317, 359, Springer, New York.

Wina, E., Muetzel, S., Hoffmann, E.M., Makkar, H.P.S., \& Becker, K., 2005, Saponin containing methanol extract of Sapindus rarak affect microbial fermentation, microbial activity and microbial community structure in vitro, Animal Feed Science Technology, 121, 59-174.

World Health Organization (WHO), 2004, Prevention and Control of Dengue and Dengue Haemorrhagic Fever, Terjemahan dari WHO Regional Publication SEARO No. 29, New Delhi 
